\title{
Evaluation of MAX-DOAS aerosol retrievals by coincident observations using CRDS, lidar, and sky radiometer in Tsukuba, Japan
}

\author{
H. Irie ${ }^{1}$, T. Nakayama ${ }^{2}$, A. Shimizu ${ }^{3}$, A. Yamazaki ${ }^{4}$, T. Nagai ${ }^{4}$, A. Uchiyama ${ }^{4}$, Y. Zaizen ${ }^{4}$, S. Kagamitani ${ }^{2}$, and \\ Y. Matsumi ${ }^{2}$ \\ ${ }^{1}$ Center for Environmental Remote Sensing, Chiba University, 1-33 Yayoicho, Inage-ku, Chiba 263-8522, Japan \\ ${ }^{2}$ Solar-Terrestrial Environment Laboratory, Nagoya University, Furo-cho, Chikusa-ku, Nagoya 464-8601, Japan \\ ${ }^{3}$ National Institute for Environmental Studies, 16-2 Onogawa, Tsukuba, Ibaraki 305-8506, Japan \\ ${ }^{4}$ Climate Research Department, Meteorological Research Institute, Japan Meteorological Agency, 1-1 Nagamine, \\ Tsukuba 305-0052, Japan
}

Correspondence to: H. Irie (hitoshi.irie@ chiba-u.jp)

Received: 21 January 2015 - Published in Atmos. Meas. Tech. Discuss.: 27 January 2015

Revised: 30 June 2015 - Accepted: 02 July 2015 - Published: 16 July 2015

\begin{abstract}
Coincident aerosol observations of multi-axis differential optical absorption spectroscopy (MAX-DOAS), cavity ring-down spectroscopy (CRDS), lidar, and sky radiometer were conducted in Tsukuba, Japan, on 5-18 October 2010. MAX-DOAS aerosol retrieval (for aerosol extinction coefficient and aerosol optical depth at $476 \mathrm{~nm}$ ) was evaluated from the viewpoint of the need for a correction factor for oxygen collision complexes $\left(\mathrm{O}_{4}\right.$ or $\left.\mathrm{O}_{2}-\mathrm{O}_{2}\right)$ absorption. The present study strongly supports this need, as systematic residuals at relatively high elevation angles (20 and $30^{\circ}$ ) were evident in MAX-DOAS profile retrievals conducted without the correction. However, adopting a single number for the correction factor $\left(f_{\mathrm{O}_{4}}=1.25\right)$ for all of the elevation angles led to systematic overestimation of nearsurface aerosol extinction coefficients, as reported in the literature. To achieve agreement with all three observations, we limited the set of elevation angles to $\leq 10^{\circ}$ and adopted an elevation-angle-dependent correction factor for practical profile retrievals with scattered light observations by a groundbased MAX-DOAS. With these modifications, we expect to minimize the possible effects of temperature-dependent $\mathrm{O}_{4}$ absorption cross section and uncertainty in DOAS fit on an aerosol profile retrieval, although more efforts are encouraged to quantitatively identify a physical explanation for the need of a correction factor.
\end{abstract}

\section{Introduction}

Atmospheric aerosols play a critical role in controlling the Earth's climate and air quality (IPCC, 2013). Due to the insufficient understanding of their complicated formation mechanisms and effects, there is a growing need to understand and measure their optical properties and precursors. Under these circumstances, simultaneous measurements of aerosols and their gaseous precursors, such as nitrogen dioxide $\left(\mathrm{NO}_{2}\right)$ and sulfur dioxide $\left(\mathrm{SO}_{2}\right)$, using the multi-axis differential optical absorption spectroscopy (MAX-DOAS) technique have been reported, with additional and significant advantages of vertical profiling, simple setup, low power consumption, and autonomous operation without absolute radiometric calibration (Hönninger and Platt 2002; Hönninger et al., 2004; Wittrock et al., 2004; Irie et al., 2008a, b, 2009, 2011). MAX-DOAS is an application of the well-established DOAS technique, with which narrow band absorption features are analyzed to selectively detect and quantify trace gases by applying the Lambert-Beer law (Platt, 1994; Platt and Stutz, 2008). In general, MAX-DOAS measures ultraviolet (UV)-visible spectra of scattered sunlight at several elevation angles $(\alpha)$ between the horizon and zenith. Within the boundary layer, for instance, observation at a low $\alpha$ yields averaged information about trace gas concentrations over a distance, which is in the same order of, or finer than, the horizontal scale usually adopted by models and measured 
by satellites but coarser than that of in situ observations. Thereby, it is expected that MAX-DOAS plays an important role in bridging different data sets with different spatial resolutions (Irie et al., 2011). Thus, observations by MAX-DOAS are highly unique and have great potential for realizing many applied studies, including those on aerosols.

The number of MAX-DOAS instruments has grown considerably in recent years (e.g., Roscoe et al., 2010; Piters et al., 2012). The increasing use of MAX-DOAS instruments for tropospheric observations, together with the diversity of their designs and operation protocols, created the need for formal comparison. For this purpose, the Cabauw Intercomparison Campaign of Nitrogen Dioxide measuring Instruments (CINDI) was held at the Cabauw measurement station $\left(51.97^{\circ} \mathrm{N}, 4.93^{\circ} \mathrm{E}\right)$, the Netherlands, in June-July 2009. During the CINDI campaign, besides the intercomparison for $\mathrm{NO}_{2}$, near-surface aerosol extinction coefficients (AECs) retrieved from observations from four different MAX-DOAS instruments were compared to those measured by the in situ humidified nephelometer (Zieger et al., 2011). The comparison showed a tight correlation at a determination coefficient $R^{2}$ of $0.62-0.78$, but the AECs from MAX-DOAS were a factor of 1.5-3.4 larger than the in situ values. The systematic differences could have been caused by the limited vertical resolution of the MAX-DOAS retrieval overestimating the AECs in the lowest layer, as lofted aerosol layers were present during the measurement period (Zieger et al., 2011; Irie et al., 2011). However, sufficient evidence for their causal link was not obtained. In relation to the discussion below, we note here that a correction factor for the absorption of oxygen collision complexes $\left(\mathrm{O}_{4}\right.$ or $\left.\mathrm{O}_{2}-\mathrm{O}_{2}\right)$ was applied to all four participating MAX-DOAS retrievals. This is based on observations by Wagner et al. (2009) and Clémer et al. (2010), who indicated that retrieved $\mathrm{O}_{4}$ slant column densities (SCDs) were systematically too high to match the model simulation under near pure Rayleigh conditions, although a physical explanation for applying the correction factor was unclear.

In the present study, coincident aerosol observations by MAX-DOAS and those by cavity ring-down spectroscopy (CRDS), lidar, and sky radiometer were conducted in Tsukuba, Japan, on 5-18 October 2010. This occasion was used to evaluate the MAX-DOAS aerosol retrievals of AECs and aerosol optical depth (AOD) at $476 \mathrm{~nm}$, particularly from the viewpoint of the need for a correction factor for $\mathrm{O}_{4}$ absorption. Potential practical solutions to achieve agreement of the MAX-DOAS observations with the three other observations are discussed.

\section{Observations}

\subsection{MAX-DOAS}

We installed our MAX-DOAS system at the Meteorological Research Institute in Tsukuba, Japan $\left(36.06^{\circ} \mathrm{N}, 140.13^{\circ} \mathrm{E}\right)$, on 1 June 2010. Because the installed MAX-DOAS system (PREDE, Co., Ltd) is basically the same as the one used for the CINDI campaign (Irie et al., 2011) and for the MAXDOAS network of $\mathrm{NO}_{2}$ in Russia and Asia (MADRAS) (Kanaya et al., 2014), only a brief description is given below. A miniaturized UV-visible spectrometer (Ocean Optics, Inc., USB4000) was used to record spectra between 223 and $557 \mathrm{~nm}$. The temperature $(T)$ of the USB4000 spectrometer was kept constant at $40.0 \pm 0.1^{\circ} \mathrm{C}$ to stabilize spectrometer characteristics and to prevent possible dew condensation. The spectral resolution (full width at half maximum) was 0.76 at $450 \mathrm{~nm}$, as estimated by wavelength calibration using a high-resolution solar spectrum (Kurucz et al., 1984). The integration time was kept constant throughout the day at $150 \mathrm{~ms}$. Spectra recorded at a fixed $\alpha$ for a $5 \mathrm{~min}$ interval were averaged and analyzed. The line of sight was directed to an azimuth angle of $316^{\circ}$ (northwest). The field of view was $<1^{\circ}$. Spectra were recoded sequentially at six different $\alpha$ of $3,5,10,20,30$, and $90^{\circ}$ using a movable mirror. This sequence was repeated every $30 \mathrm{~min}$.

Spectral analysis and subsequent profile retrieval were performed using our new version of the Japanese MAX-DOAS profile retrieval algorithm, version 2, which is the updated version of the JM1 (Irie et al., 2011) used for CINDI. Because most parts are the same as the JM1, some detailed descriptions have been omitted in this paper. The recoded spectra were first analyzed by the so-called DOAS method (Platt, 1994; Platt and Stutz, 2008), in which spectral fitting is performed using the nonlinear least-squares method (Irie et al., 2008a). The DOAS method retrieves the differential slant column density $(\triangle \mathrm{SCD})$, defined as the difference between the SCD along the path of sunlight for off-axis measurements $\left(\alpha<90^{\circ}\right)$ and the SCD for the reference measurement $\left(\alpha=90^{\circ}\right)$. Most of the absorption cross-section data used here were the same as those used during the CINDI campaign (Roscoe et al., 2010). For $\mathrm{H}_{2} \mathrm{O}$, we used the 2009 edition of the High-Resolution Transmission (HITRAN) database. For $\mathrm{O}_{4}$, Hermans' cross-section data at $296 \mathrm{~K}$ (Herman, 2011) were used. Results obtained using the newly available $\mathrm{O}_{4}$ cross-section data of Thalman and Volkamer (2013) are discussed later.

The fitting window of $460-490 \mathrm{~nm}$ was analyzed for aerosol retrievals at $476 \mathrm{~nm}$. The wavelength corresponds to the $\mathrm{O}_{4}$-cross-section-weighted mean wavelengths for the fitting window. The fitting window was chosen to minimize the wavelength dependence of the air mass factor (AMF) information between representative wavelengths for $\mathrm{O}_{4}$ and $\mathrm{NO}_{2}$. $\mathrm{NO}_{2}$ is the primary target gas for our MAX-DOAS observations (Irie et al., 2011). The retrieved quantity, $\triangle \mathrm{SCD}$ of $\mathrm{O}_{4}$, is referred to as the $\triangle \mathrm{SCD}$ for quadratic $\mathrm{O}_{2}$ concentration (molecules $\mathrm{cm}^{-5}$ ) and therefore contains the equilibrium constant between $\mathrm{O}_{4}$ and two $\mathrm{O}_{2}$ molecules (Greenblatt et al., 1990).

A set of $\mathrm{O}_{4} \triangle \mathrm{SCD}$ data obtained at all $\alpha$ was inverted into the vertical profile of AECs at $476 \mathrm{~nm}$. The nonlinear 
inversion problem was solved by the Optimal Estimation Method (Rodgers, 2000). To create a lookup table (LUT) of the box-AMF vertical profile, which was required to calculate $\mathrm{O}_{4} \triangle \mathrm{SCD}$ in the forward model, we used the radiative transfer model JACOSPAR. The JACOSPAR was developed based on its predecessor, the Monte Carlo Atmospheric Radiative Transfer Simulator (MCARaTS) (Iwabuchi, 2006). Box-AMF calculations by MCARaTS have been validated by other radiative transfer models (Wagner et al., 2007). To simulate a realistic atmosphere, we considered the surface altitude at the measurement site $(35 \mathrm{~m}$ a.s.1.) and the altitude where the instrument was located (63 $\mathrm{m}$ a.s.l). In addition, in the forward model, temporal variations in ambient temperature and pressure based on National Centers for Environmental Prediction surface data were considered.

In this inversion, components of the measurement vector were set to $\mathrm{O}_{4} \Delta \mathrm{SCD}$ values at all $\alpha$ for a full $\alpha$ scanning time of $30 \mathrm{~min}$. Here, the $\mathrm{O}_{4} \Delta \mathrm{SCD}$ value derived from observations is denoted as $\mathrm{O}_{4} \triangle \mathrm{SCD}$ (obs) and that calculated by the forward model is denoted as $\mathrm{O}_{4} \triangle \mathrm{SCD}$ (mdl). If the inversion was perfectly finished, the $\mathrm{O}_{4} \Delta \mathrm{SCD}$ (mdl) should be identical to $\mathrm{O}_{4} \Delta \mathrm{SCD}$ (obs) within the range corresponding to measurement noises. However, if the systematic residual remained, these two quantities could be linked by the following:

$\mathrm{O}_{4} \Delta \mathrm{SCD}(\mathrm{mdl}) \times f_{\mathrm{O}_{4}}=\mathrm{O}_{4} \Delta \mathrm{SCD}(\mathrm{obs})$

or

$f_{\mathrm{O}_{4}}=\mathrm{O}_{4} \Delta \mathrm{SCD}(\mathrm{obs}) / \mathrm{O}_{4} \Delta \mathrm{SCD}(\mathrm{mdl})$,

where $f_{\mathrm{O}_{4}}$ is the correction factor for $\mathrm{O}_{4} \Delta \mathrm{SCD}$ (mdl). This factor was introduced to compensate for a possible discrepancy between $\mathrm{O}_{4} \Delta \mathrm{SCD}$ (obs) and $\mathrm{O}_{4} \Delta \mathrm{SCD}$ (mdl). For instance, a discrepancy could occur if there were a bias in $\mathrm{O}_{4}$ $\triangle \mathrm{SCD}$ (mdl) due to a bias in $\mathrm{O}_{4}$ absorption cross-section data. For the CINDI campaign, the adopted $f_{\mathrm{O}_{4}}$ values (and their reciprocals, as described by Zieger et al., 2011) ranged from $1.20(0.83)$ to $1.33(0.75)$, depending on the participating group (Zieger et al., 2011). Our JM1 algorithm adopted 1.25 (0.80), according to Clémer et al. (2010).

With the above setup, we retrieved four parameters, which were used to construct the continuous AEC vertical profile. The state vector $(\boldsymbol{x})$ was then defined as

$\boldsymbol{x}=\left(\begin{array}{llll}\mathrm{AOD} & F_{1} & F_{2} & F_{3}\end{array}\right)^{T}$.

The $F$ values that range between 0 and 1 are the parameters determining the shape of the vertical profile. Partial AOD values for $0-1,1-2$, and $2-3 \mathrm{~km}$ are given as $\mathrm{AOD} \times F_{1}$, $\mathrm{AOD} \times\left(1-F_{1}\right) F_{2}$, and $\mathrm{AOD} \times\left(1-F_{1}\right)\left(1-F_{2}\right) F_{3}$, respectively, and the partial AOD above $3 \mathrm{~km}$ as AOD $\times(1-$ $\left.F_{1}\right)\left(1-F_{2}\right)\left(1-F_{3}\right)$. From the partial AOD above $3 \mathrm{~km}$, we determined a continuous AEC profile for the layer from 3 to $100 \mathrm{~km}$ assuming an AEC value at the top of the layer

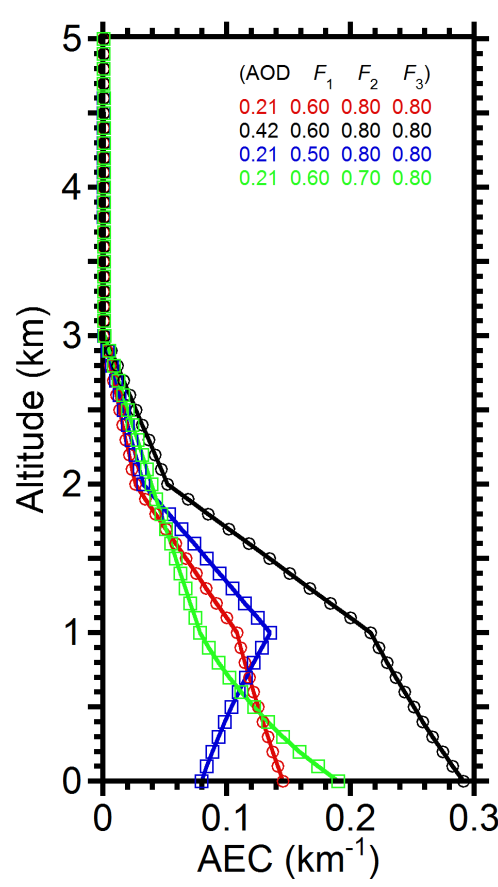

Figure 1. Examples of aerosol extinction coefficient (AEC) profiles retrieved from MAX-DOAS observations. These are derived from four parameters of AOD, $F_{1}, F_{2}$, and $F_{3}$, as described in detail in the text. Parameters used are given in the plot.

$(100 \mathrm{~km})$ and an exponential profile shape. Similarly, we determined continuous profiles for layers of $2-3,1-2$, and 0 $1 \mathrm{~km}$. Examples of AEC vertical profiles parameterized in this way are shown in Fig. 1. The a priori profile is shown in red. When AOD was doubled, the AEC profile was simply scaled by a factor of 2 (Fig. 1). Increasing the $F_{1}$ value, for example, led to a greater fraction of AOD below $1 \mathrm{~km}$, resulting in a steep gradient of the AEC profile below $1 \mathrm{~km}$. When the $F_{1}$ value decreased, the fraction of AOD below $1 \mathrm{~km}$ decreased. This resulted in a reduction of the gradient, and the representation of an uplifted aerosol profile was possible (Fig. 1).

The a priori values ( \pm error) used in the present study were the same as those used for CINDI (Irie et al., 2011): $\mathrm{AOD}=0.21 \pm 3.0, F_{1}=0.60 \pm 0.05, F_{2}=0.80 \pm 0.03$, and $F_{3}=0.80 \pm 0.03$. These yield an AEC of $0.13 \mathrm{~km}^{-1}$ as the mean values for the $0-1 \mathrm{~km}$ layer. The corresponding error is $+2.22 /-1.94 \mathrm{~km}^{-1}$, indicating the allowance for retrieving a wide range of AECs. Non-diagonal elements of the a priori covariance matrix were set to 0 .

Output from the vertical profile retrieval was only available for retrieved AOD less than 3, which corresponds to the largest value in the LUT. This excludes large optical depth cases, most of which should be due to optically thick clouds. Further data screening was made using the root-mean squares of the residuals of the $\mathrm{O}_{4} \Delta \mathrm{SCD}$ values. Larger residuals could occur when the above-mentioned method of construct- 
ing a vertical profile was too simple to represent the true profile, particularly with a very steep vertical gradient of extinction due to clouds. In addition, rapid changes in optical depth within the full $\alpha$ scanning time of 30 min could lead to larger residuals. The threshold for these data screening was set to $10 \%$ of the mean $\mathrm{O}_{4} \triangle \mathrm{SCD}$ (obs) in each $30 \mathrm{~min}$ interval.

\subsection{CRDS}

The CRDS instrument typically consists of two highreflectivity plano-concave mirrors set opposite one another. A pulsed or continuous laser beam is coupled into the cavity from one side, and performs multiple reflections inside the cavity. A photodetector is placed at the other side of the cavity and measures the exponential decay of the light intensity transmitted through the cavity. By comparing the decay rates measured in the presence and absence of aerosols, the AECs can be determined.

At Tsukuba from 5 to 18 October 2010, the AECs at 355 and $532 \mathrm{~nm}$ were measured using a custom-built $2 \lambda$-CRDS (Nakayama et al., 2010a, b). Ambient particles were sampled through the $\mathrm{PM}_{10}$ inlet placed $54 \mathrm{~m}$ a.s.l. The decay rates in the absence of aerosols were measured for $5 \mathrm{~min}$ every $20 \mathrm{~min}$ by passing the particles through a high efficiency particulate air filter (Pall). To determine the relative humidity $(\mathrm{RH})$ dependence of the AEC values, the AECs were measured under high $\mathrm{RH}$ conditions $(\mathrm{RH}=79.0 \pm 0.6 \%)$ by passing the particles through a humidifier (Perma Pure LLC, MD-110-24S-4) for $20 \mathrm{~min}$ every $60 \mathrm{~min}$. The RH and temperature in the cells were monitored using thermohygrometers (Vaisala, HMT-337). The $60 \mathrm{~min}$ average exponential dependence parameter of extinction on $\mathrm{RH}(\gamma)$ was calculated using a series of 20 min averages of AEC and RH data as follows:

$\mathrm{AEC}_{\mathrm{RH}_{1}}(\lambda) / \mathrm{AEC}_{\mathrm{RH}_{2}}(\lambda)=\left[\left(100-\mathrm{RH}_{1}\right) /\left(100-\mathrm{RH}_{2}\right)\right]^{-\gamma}$,

where $\mathrm{AEC}_{\mathrm{RH}_{1}}(\lambda)$ and $\mathrm{AEC}_{\mathrm{RH}_{2}}(\lambda)$ are $\mathrm{AEC}$ values measured at $\mathrm{RH}_{1}$ and $\mathrm{RH}_{2}$, when aerosols were passed through the humidifier. The AECs $\left(\operatorname{AEC}_{\mathrm{amb}}(\lambda)\right)$ corresponding to the ambient $\mathrm{RH}\left(\mathrm{RH}_{\mathrm{amb}}\right)$, temperature, and pressure conditions were then calculated using the $\gamma$ values:

$$
\begin{aligned}
& \operatorname{AEC}_{\mathrm{amb}}(\lambda)=\left(T_{\text {cell }} P_{\mathrm{amb}} / T_{\mathrm{amb}} P_{\text {cell }}\right) \\
& \times \mathrm{AEC}_{\mathrm{RH}_{\text {cell }}}(\lambda)\left[\left(100-\mathrm{RH}_{\mathrm{amb}}\right) /\left(100-\mathrm{RH}_{\text {cell }}\right)\right]^{-\gamma},
\end{aligned}
$$

where $T_{\text {cell }}$ and $T_{\text {amb }}$ are temperatures, and $P_{\text {cell }}$ and $P_{\text {amb }}$ are pressures in the cell and ambient air, respectively. The $60 \mathrm{~min}$ averaged $\mathrm{AEC}_{\mathrm{amb}}(476 \mathrm{~nm})$ was estimated from the obtained $\mathrm{AEC}_{\mathrm{amb}}(355 \mathrm{~nm})$ and $\mathrm{AEC}_{\mathrm{amb}}(532 \mathrm{~nm})$ using the extinction Ångström exponent between 355 and $532 \mathrm{~nm}$ and was used for comparison with the MAX-DOAS data. The average $( \pm 1 \sigma)$ relative uncertainty in the 60 min average $\mathrm{AEC}_{\mathrm{amb}}$ $(476 \mathrm{~nm})$ values was estimated to be $11( \pm 7) \%$ from the un- certainties in the AEC measurements at 355 and $532 \mathrm{~nm}$ and in the corrections for $\mathrm{RH}$ and wavelength dependence.

During the CRDS measurements, aerosol scattering and absorption coefficients (ASC and AAC, respectively) were also measured using a $3 \lambda$ nephelometer (TSI, model 3563 , $450,550,700 \mathrm{~nm})$ and a $3 \lambda$-particle soot absorption photometer (PSAP) (Radiance Research, 467, 530, $660 \mathrm{~nm}$ ) (Uchiyama et al., 2014). The nephelometer data were corrected using the scattering Ångström-exponent-dependent correction factors reported by Anderson and Ogren (1998). The PSAP data were corrected based on the scheme reported by Ogren (2010). These corrected data were used for comparison with the CRDS data after taking into account the difference in the RH, temperature, and pressure in the cells, as well as the difference in wavelength. The AACs at 450 and $550 \mathrm{~nm}$ were estimated using the absorption Ångström exponent between 462 and $526 \mathrm{~nm}$ and between 526 and $650 \mathrm{~nm}$, respectively, assuming that the AACs were independent of RH. The AECs at 355 and $532 \mathrm{~nm}$ obtained by the CRDS were corrected to the values corresponding to the RH in the cell of nephelometer using the $\gamma$ values. Then, the AEC values at 450 and $550 \mathrm{~nm}$ were estimated using the extinction Ångström exponent and used for the comparison with the nephelometer and PSAP data. The AECs estimated from the CRDS data showed good agreement with the sum of the ASCs measured by the TSI nephelometer and the AACs estimated from PSAP data, with a slope of $1.01\left(R^{2}=0.94\right)$ and $1.00\left(R^{2}=0.93\right)$ at 450 and $550 \mathrm{~nm}$, respectively.

\subsection{Lidar}

The lidar system operated was a compact Mie-scattering system utilizing the fundamental and second harmonics of a flashlamp-pumped neodymium-doped yttrium aluminum garnet (Nd:YAG) laser $(1064 / 532 \mathrm{~nm})$ as the light source (Shimizu et al., 2004). To solve the lidar equation, we assumed a constant extinction-to-backscattering ratio $(S)$ of 50 sr. The $S$ ratio can vary by more than $30 \%$ at Tsukuba, with resulting errors in AEC due to the use of a fixed $S$ occasionally exceeding $30 \%$ (Irie et al., 2008a). In quantitative discussion of AEC values near the surface, the lidar aerosol extinction data at $532 \mathrm{~nm}$ were converted into AEC value at $476 \mathrm{~nm}$, which can be compared to the MAX-DOAS data, using coincident measurements of the Ångström exponent by the CRDS. During the time period of this comparative observation, lidar data were sometimes affected by clouds. In cases where clouds were present below $6 \mathrm{~km}$, an AEC profile was retrieved from data below the cloud base. This is not the preference for the lidar data analysis and is potentially the reason for the large uncertainty in derived AEC values below clouds. Due to the lack of overlap between the laser beam and the field of view of the telescope, the lowest height of retrieved AECs was $120 \mathrm{~m}$. Thereafter, assuming homogeneous mixing of aerosols below this altitude, we assumed 


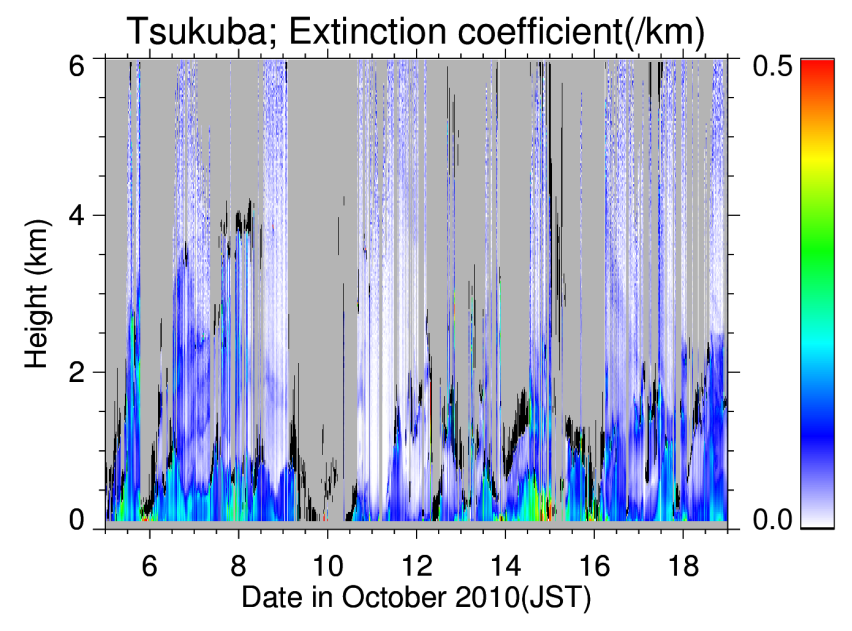

Figure 2. Vertical profiles of AEC values at $532 \mathrm{~nm}$ derived from lidar observations. Black indicates the regions between the cloud base and apparent cloud top. Gray corresponds to invisible regions above clouds.

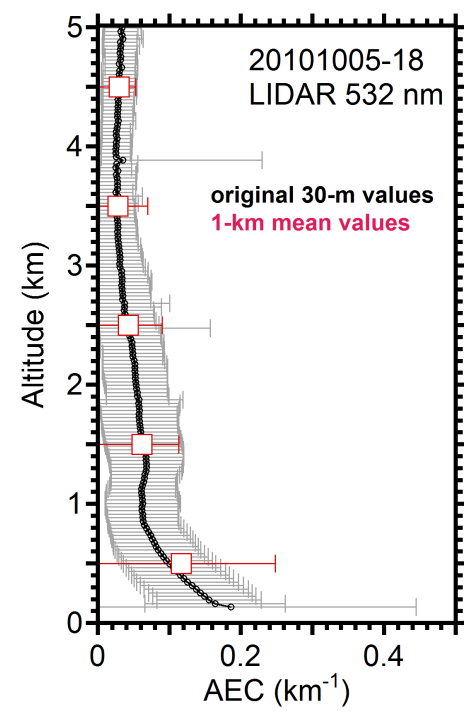

Figure 3. Mean vertical profiles of lidar AEC data at $532 \mathrm{~nm}$ for 5-18 October 2010. Profiles with the original vertical resolution $(30 \mathrm{~m})$ and $1 \mathrm{~km}$ mean profiles are shown in black and red, respectively. In this period, there are significant amounts of AECs even above $2 \mathrm{~km}$. Error bars represent $1 \sigma$ standard deviations.

constant AEC values and their errors in the vertical direction below $120 \mathrm{~m}$.

\subsection{Sky radiometer}

A scanning sun-sky photometer called the sky radiometer (Prede Co., Ltd, Tokyo, Japan) is the main instrument in the ground-based observation network SKYNET (Nakajima et al., 2007). A set of measurements of the direct solar irradiance and the solar radiance distributions was made with
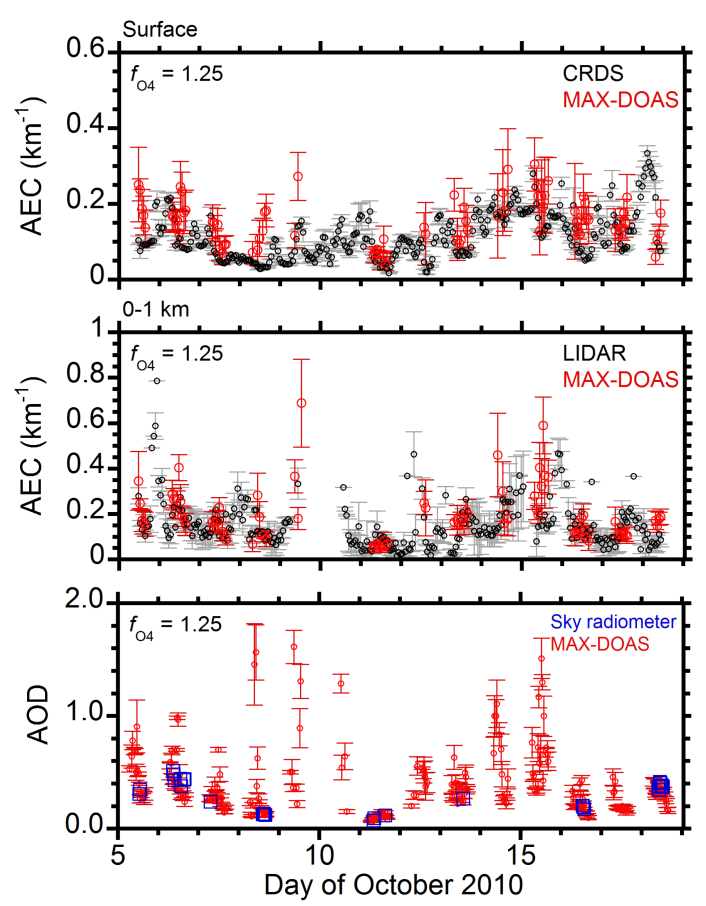

Figure 4. Time series of $\mathrm{AEC}$ and $\mathrm{AOD}$ values at $476 \mathrm{~nm}$ on 5-18 October 2010. (Top) Near-surface AEC values from CRDS and MAX-DOAS; (middle) AEC values for $0-1 \mathrm{~km}$ from lidar and MAX-DOAS; (bottom) AOD values from sky radiometer and MAX-DOAS are compared in respective plots. For the MAXDOAS retrieval, a $f_{\mathrm{O}_{4}}$ of 1.25 is assumed. Error bars for MAXDOAS represent uncertainty associated with the retrieval. Error bars for CRDS represent the $1 \sigma$ values estimated from the uncertainties in the AEC measurements at 355 and $532 \mathrm{~nm}$ and in the corrections for RH and wavelength dependence. Error bars for lidar represent $1 \sigma$ standard deviations of original $30 \mathrm{~m}$ AEC values in the $0-1 \mathrm{~km}$ layer.

the sky radiometer in $30 \mathrm{~s}$ to $2 \mathrm{~min}$, depending on the solar zenith angle. This was repeated every $10 \mathrm{~min}$. The data were analyzed to derive the aerosol optical properties (such as AOD) at $340,380,400,500,675,870$, and $1020 \mathrm{~nm}$ using the SKYRAD.pack version 4.2 software package (Nakajima et al., 1996). The Ångström exponent was calculated from these AOD values and was used to derive AOD values at $476 \mathrm{~nm}$. Aerosol optical properties retrieved from sky radiometers/SKYNET have been used to investigate regional and seasonal characteristics of aerosols for climate and environmental studies and to validate satellite remote sensing results (Higurashi and Nakajima, 2002; Kim et al., 2005; Sohn et al., 2007; Pandithurai et al., 2009; Campanelli et al., 2010; Khatri et al., 2010; Takenaka et al., 2011). There are several reports that the AOD values obtained have high accuracy compared to those of the standard Langley method and those from AERONET (Campanelli et al., 2007; Che et al., 2008). 

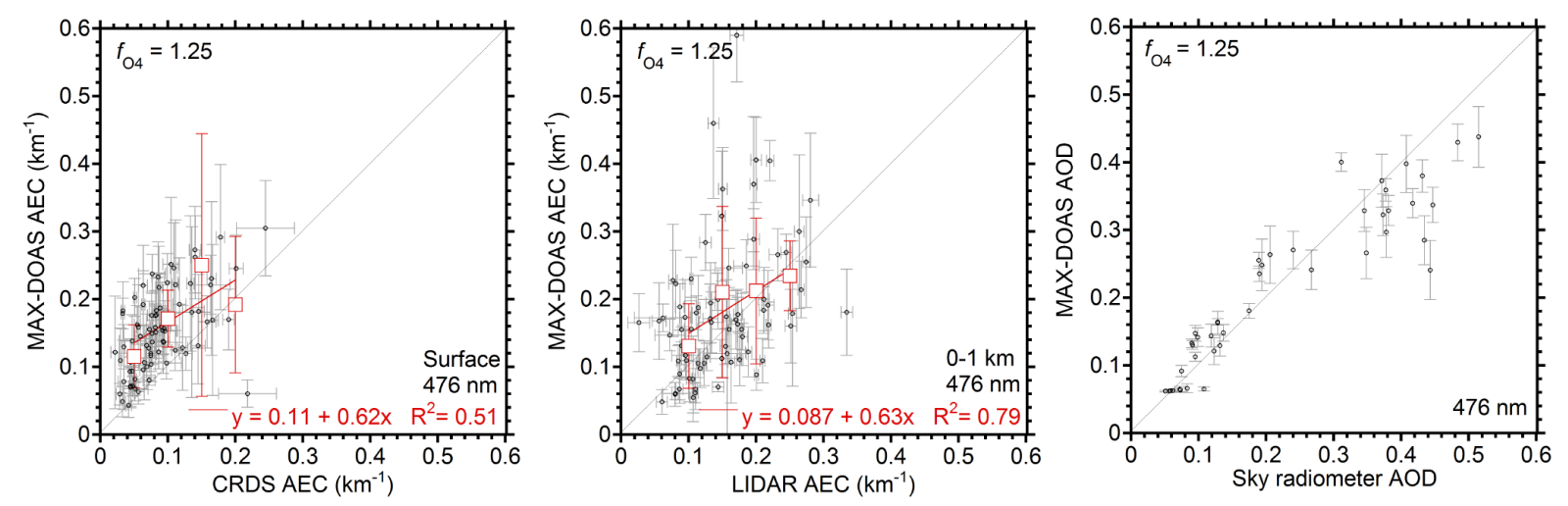

Figure 5. Correlation plots (left) between near-surface AEC values from CRDS and MAX-DOAS, (center) between mean AEC values for 0-1 km from lidar and MAX-DOAS, and (right) between AOD values from sky radiometer and MAX-DOAS. In AEC plots, red symbols show the averages of the MAX-DOAS AEC values for each $0.05 \mathrm{~km}^{-1}$ bin of CRDS or lidar data. The bin has been optimized considering the number of bins and the number of data in each bin for all pairs of comparisons in this study. For the MAX-DOAS retrieval, a $f_{\mathrm{O}_{4}}$ of 1.25 is assumed.

\section{Results and discussion}

Temporal variations in vertical profiles of AECs at $532 \mathrm{~nm}$ derived from lidar observations at Tsukuba for the period of 5-18 October 2010 are shown in Fig. 2. This time period can be characterized as a rather ordinary period with moderate cloud occurrence. In addition, it can be seen that most aerosols were located below an altitude of $\sim 2 \mathrm{~km}$, and significant, prolonged uplifted aerosols were not observed. This differs from the situation during the CINDI campaign period, when the uplifted aerosols could be attributed to the discrepancy found in comparisons between MAX-DOAS and the ground-based humidified nephelometer (Zieger et al., 2011; Irie et al., 2011). In Fig. 3, the mean vertical profile of lidar AEC data taken on 5-18 October is plotted. Mean AECs above $3 \mathrm{~km}$ were about $0.03 \mathrm{~km}^{-1}$. Above $3 \mathrm{~km}$, MAX-DOAS has a weak sensitivity to aerosols and the JM2 vertical profile retrieval algorithm employs a parameterization that does not allow a significant number of AECs (Fig. 1). This easily results in the underestimation of AECs above $3 \mathrm{~km}$ and AOD.

In Figs. 4 and 5, MAX-DOAS aerosol data are compared to CRDS AECs, lidar AECs, and sky radiometer AOD data. The comparisons were made for a wavelength of $476 \mathrm{~nm}$. In the MAX-DOAS retrieval, a $f_{\mathrm{O}_{4}}$ of 1.25 was assumed, following the procedure taken in the CINDI campaign (Irie et al., 2011). In general, temporal variation showed very similar patterns (Fig. 4). A problem found in the comparisons is that most of the MAX-DOAS AEC values at the nearsurface level show values larger than CRDS values (Fig. 5). The AECs from MAX-DOAS were larger than CRDS values by a factor of $\sim 1-4$, which is comparable to that found by Zieger et al. (2011) from similar comparisons during CINDI (a factor of 1.5-3.4). The important point is that the systematic differences seen in the MAX-DOAS/CRDS comparisons
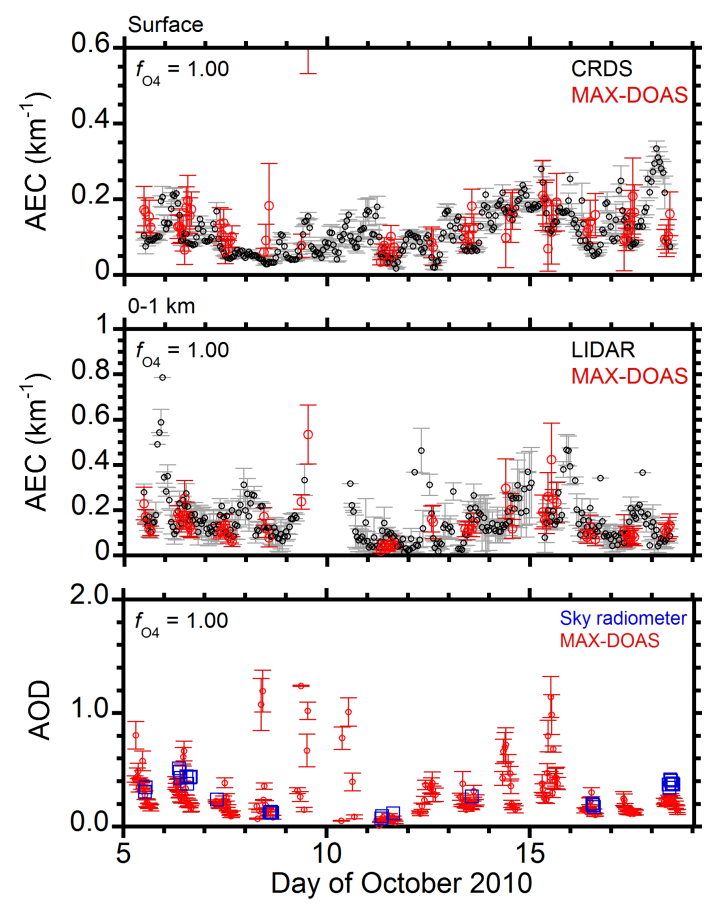

Figure 6. Same as Fig. 4, but a $f_{\mathrm{O}_{4}}$ of 1.00 is assumed in the MAXDOAS retrieval.

occurred even when uplifted aerosol layers were not often present during the observation period of this study (Fig. 1). This indicates that the occurrence of uplifted aerosols is not the major reason causing significant differences.

As a physical reason for applying this correction factor is unclear, other comparisons were made assuming $f_{\mathrm{O}_{4}}=1.00$ (i.e., no correction applied) for MAX-DOAS retrievals (Figs. 6 and 7). For comparisons made at the near surface and at $0-1 \mathrm{~km}$, the retrievals assuming $f_{\mathrm{O}_{4}}=1.00$ 

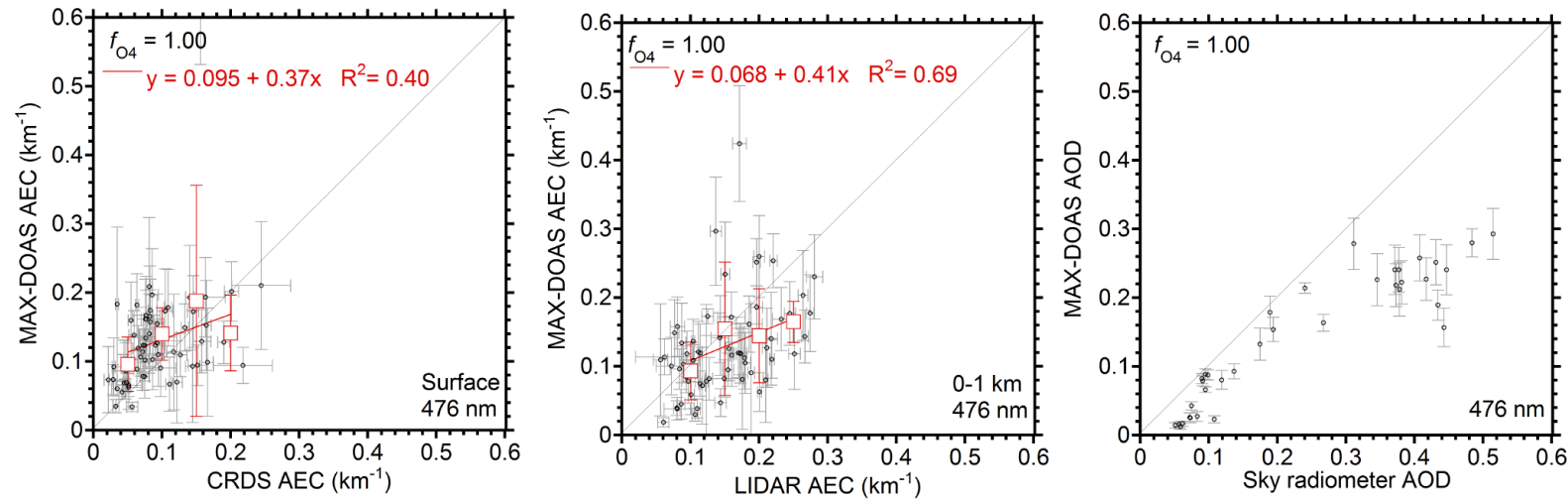

Figure 7. Same as Fig. 5, but a $f_{\mathrm{O}_{4}}$ of 1.00 is assumed in the MAX-DOAS retrieval.

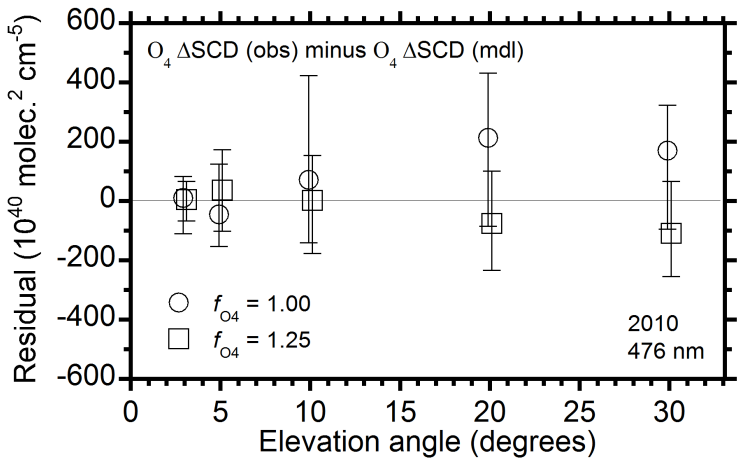

Figure 8. Median values of residuals, $\mathrm{O}_{4} \Delta \mathrm{SCD}$ (obs) minus $\mathrm{O}_{4}$ $\triangle \mathrm{SCD}$ (mdl), as a function of elevation angle. Values for retrievals with $f_{\mathrm{O}_{4}}=1.00$ and $f_{\mathrm{O}_{4}}=1.25$ are plotted with circles and squares, respectively. Error bars represent $67 \%$ ranges.

brought MAX-DOAS AEC values closer to CRDS and lidar data than those assuming $f_{\mathrm{O}_{4}}=1.25$. The mean differences of MAX-DOAS AEC values from CRDS and lidar data were improved from $+0.07 \pm 0.09$ and $+0.03 \pm 0.10 \mathrm{~km}^{-1}$ to $+0.04 \pm 0.08$ and $-0.02 \pm 0.07 \mathrm{~km}^{-1}$, respectively. At the same time, however, almost all of the MAX-DOAS AOD values showed underestimation. In addition, simple linear regression analyses show rather poor correlations with CRDS and lidar AEC data at $R^{2}$ of $\sim 0.4$ and 0.7 , respectively. Furthermore, the number of MAX-DOAS aerosol data that survived after retrievals and data screening becomes much smaller $(N=107)$ compared to that for retrievals with $f_{\mathrm{O}_{4}}=1.25(N=157)$. This is due to poor $\mathrm{O}_{4} \Delta \mathrm{SCD}$ fitting results with relatively high residuals, particularly at high $\alpha$, as discussed in detail below.

To search for the cause, we focused on median values of residuals for profile retrievals, $\mathrm{O}_{4} \Delta \mathrm{SCD}$ (obs) minus $\mathrm{O}_{4} \triangle \mathrm{SCD}(\mathrm{mdl})$, as a function of $\alpha$. As shown in Fig. 8, we found that the residuals were very small $\left(<10^{42}\right.$ molecules $\mathrm{cm}^{-5}$ ) at $\alpha \leq 10^{\circ}$. However, the residuals were relatively large at $\alpha$ of 20 and $30^{\circ}$. In particular, for retrievals

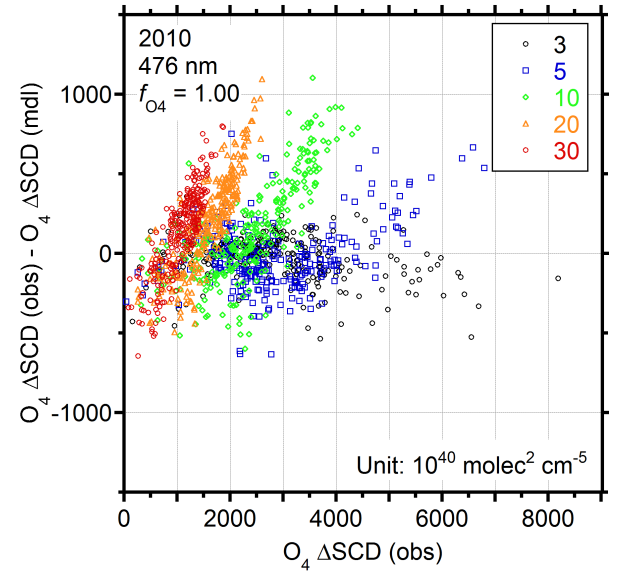

Figure 9. Individual profile retrieval residuals, $\mathrm{O}_{4} \Delta \mathrm{SCD}$ (obs) minus $\mathrm{O}_{4} \Delta \mathrm{SCD}$ (mdl), as a function of $\mathrm{O}_{4} \Delta \mathrm{SCD}$ (obs). Values for retrievals with $f_{\mathrm{O}_{4}}=1.00$ are plotted. Values for $\alpha$ of 3, 5, 10, 20, and $30^{\circ}$ are shown in black, blue, green orange, and red, respectively.

adopting $f_{\mathrm{O}_{4}}=1.00, \mathrm{O}_{4} \Delta \mathrm{SCD}$ (obs) values tended to be systematically larger than $\mathrm{O}_{4} \Delta \mathrm{SCD}$ (mdl) values, indicating that the model values were underestimated. Clémer et al. (2010) compared the measured and simulated $\mathrm{O}_{4} \Delta \mathrm{SCDs}$ at $\alpha$ of 15 and $30^{\circ}$ and found that values of the $\triangle \mathrm{SCD}(\mathrm{mdl})$ values were systematically $25 \pm 10 \%$ smaller than the measured ones.

As found in MAX-DOAS/CRDS comparisons made earlier, applying a single number for the correction factor $\left(f_{\mathrm{O}_{4}}=1.25\right)$ to all $\alpha$ yielded significant deviations in MAXDOAS AEC values from the CRDS data. In contrast, when no correction factor was applied, agreement was improved. These results gave us an idea that a different magnitude of correction factor should be applied for different $\alpha$, if a correction factor is needed.

To check if the correction factor is needed and to further estimate empirically the required correction factor from 


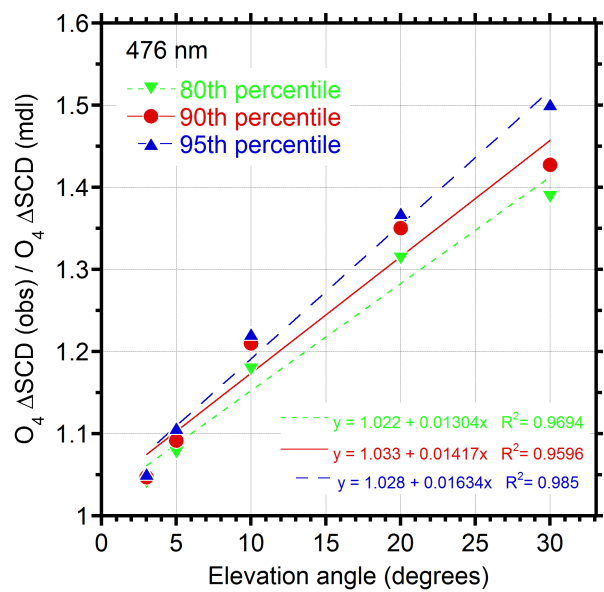

Figure 10. Relationships of 80,90 , and 95th percentiles of $\mathrm{O}_{4}$ $\Delta \mathrm{SCD}(\mathrm{obs}) / \mathrm{O}_{4} \Delta \mathrm{SCD}(\mathrm{mdl})$ with $\alpha$.

measurements, we analyzed the residuals of $\mathrm{O}_{4} \Delta \mathrm{SCDs}$ that arose from individual retrievals for the case of $f_{\mathrm{O}_{4}}=1.00$. As also seen from analysis of their median values (Fig. 8), the individual residual was usually small at the lowest $\alpha\left(3^{\circ}\right)$ (Fig. 9). While the lowest $\alpha$ is usually most important in determining near-surface AEC, the MAX-DOAS AECs retrieved with a $f_{\mathrm{O}_{4}}=1.00$ agreed well with the CRDS values, as discussed above. This may suggest that no significant correction factor is needed (i.e., the correction factor would be close to unity) for the lowest $\alpha$. In contrast, the residuals tended to be greater at higher $\alpha$. In particular, as clearly seen at $\alpha$ of 10,20 , and $30^{\circ}$, the residual increases with an increase in $\mathrm{O}_{4} \triangle \mathrm{SCD}$ (obs).

In principle, the $\mathrm{O}_{4} \Delta \mathrm{SCD}$ (mdl) has the upper limit that corresponds to pure Rayleigh conditions. Under ambient conditions with a certain amount of aerosols near the ground, the upper limit for the $\mathrm{O}_{4} \Delta \mathrm{SCD}$ (mdl) values is approximated to correspond to conditions of very low aerosols above the near-ground aerosol layer. When the $\mathrm{O}_{4} \Delta \mathrm{SCD}$ (obs) values are greater than the upper limit, their difference emerges as the residual. This happened in our retrievals, as indicated by the clear linear correlations between the residual and the $\mathrm{O}_{4} \Delta \mathrm{SCD}$ (obs) for high $\alpha$ in Fig. 9.

To estimate the correction factor needed to explain the discrepancy found in the fitting residuals, we investigated the ratio $(R)$ of $\mathrm{O}_{4} \Delta \mathrm{SCDs}$ (obs) to $\mathrm{O}_{4} \Delta \mathrm{SCDs}$ (mdl). An $R$ ratio close to unity means that the $\mathrm{O}_{4} \triangle \mathrm{SCD}$ (obs) is explained by the $\mathrm{O}_{4} \Delta \mathrm{SCD}(\mathrm{mdl})$ with retrieved aerosol profiles. An $R$ ratio smaller than unity is potentially explained by artificially adding more aerosols in the retrieved aerosol profiles, when AEC values are underestimated in the retrieved profiles. Similarly, an $R$ ratio larger than unity can be explained by artificially lowering AEC values.

Here, we make the hypothesis that a correction factor is needed. If so, the correction factor $f_{\mathrm{O}_{4}}$ should correspond to the largest $R$ to compensate for as much residuals as possible.
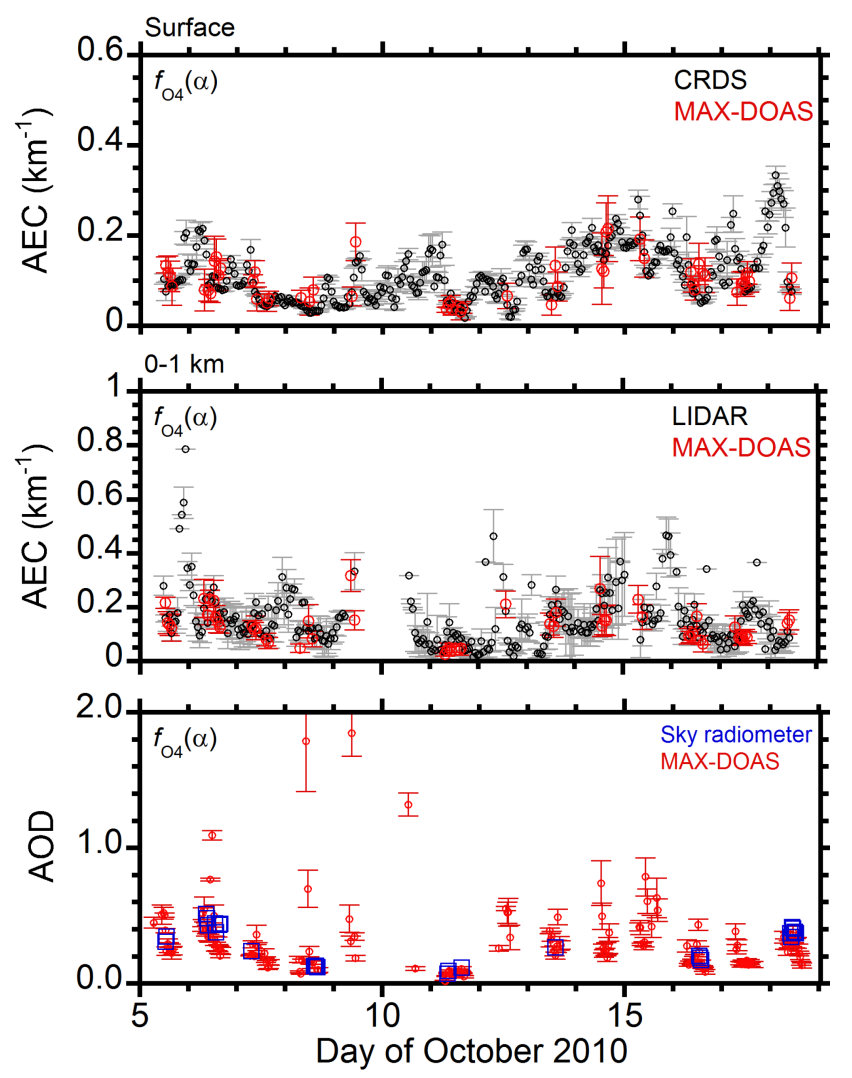

Figure 11. Same as Fig. 4, but $f_{\mathrm{O}_{4}}$ is assumed to be a function of $\alpha$ in the MAX-DOAS retrieval.

Considering that the estimate of $R$ itself had uncertainty, the largest $R$ was estimated to be approximate to the 80th, 90th, and 95th percentiles for each $\alpha$. The largest $R$ values estimated in this way are plotted as a function of $\alpha$ in Fig. 10. We found clear relationships between the largest $R$ and $\alpha$. Interestingly, the regression lines pass over the point of $R$ at $\sim 1.25$ at an $\alpha$ of $15^{\circ}$, consistent with the estimate of the correction factor by Clémer et al. (2010) for the $\alpha$ of $15^{\circ}$. This strongly supports the hypothesis that a correction factor is needed, particularly for high $\alpha$.

From these results, we derived the $\alpha$-dependent correction factor as

$f_{\mathrm{O}_{4}}=f_{\mathrm{O}_{4}}(\alpha)=1+\alpha / 60$.

Using this empirical equation, retrievals of AEC and AOD were performed. Updated results for comparisons with CRDS AECs, lidar AECs, and sky radiometer AOD data are shown in Figs. 11 and 12. Compared to the results presented earlier, reasonable agreements can be seen for the three comparisons with CRDS, lidar, and sky radiometer. For comparisons with CRDS and lidar AEC data, the values of determination coefficient $R^{2}$ were as high as 0.96 and 0.89 , respectively. The mean differences of MAX-DOAS AEC values from CRDS and lidar data were as small as $+0.01 \pm 0.04$ and $-0.03 \pm 0.05 \mathrm{~km}^{-1}$, respectively. 

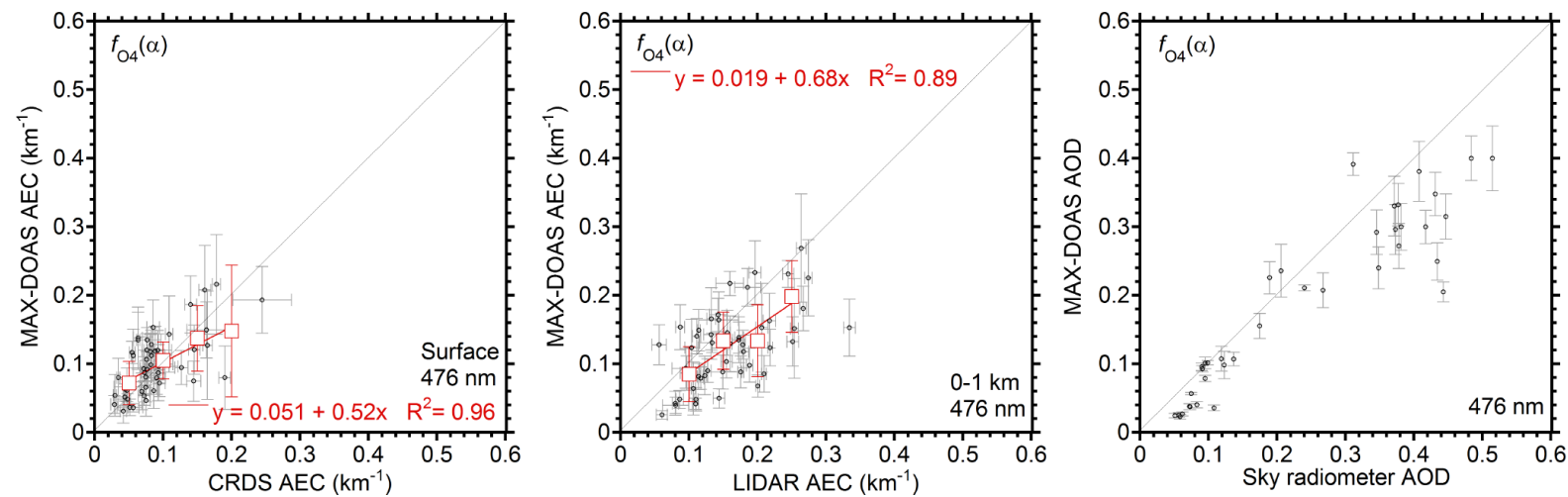

Figure 12. Same as Fig. 5, but $f_{\mathrm{O}_{4}}$ is assumed to be a function of $\alpha$ in the MAX-DOAS retrieval.

Table 1. Estimates of effective temperatures $\left(T_{\text {eff }}\right)$ for $\mathrm{O}_{4}$ absorption for an AOD (476 nm) of 0.1 , a solar zenith angle of $45^{\circ}$, and a relative azimuth angle of $180^{\circ}$. Surface temperature and pressure are assumed to be $292 \mathrm{~K}$ and $986 \mathrm{hPa}$, respectively, according to mean values at Tsukuba during the observation period.

\begin{tabular}{llllll}
\hline Elevation angle $\left(^{\circ}\right)$ & 3 & 5 & 10 & 20 & 30 \\
\hline SCD-based $T_{\text {eff }}(\mathrm{K})$ & 277 & 275 & 272 & 270 & 268 \\
$\Delta$ SCD-based $T_{\text {eff }}(\mathrm{K})$ & 283 & 279 & 276 & 274 & 271 \\
\hline
\end{tabular}

However, this empirical equation for the correction factor should be used with caution, unless the physical explanations underpinning it are clarified. One potential reason for the need for the correction factor is that $\mathrm{O}_{4} \Delta \mathrm{SCD}$ (obs) is less accurate (more overestimated) at higher $\alpha$. In fact, the nature of molecular interactions in $\mathrm{O}_{4}$ is still under discussion (e.g., Sneep et al., 2006). Recently, Thalman and Volkamer (2013) performed laboratory measurements of the absorption cross section of $\mathrm{O}_{4}, \sigma\left(\mathrm{O}_{4}\right)$ at a pressure close to ambient $(825 \mathrm{hPa})$. Their $\sigma\left(\mathrm{O}_{4}\right)$ data at $295 \mathrm{~K}$ agreed with Hermans (2011) $\sigma\left(\mathrm{O}_{4}\right)$ at $296 \mathrm{~K}$ within instrumental measurement errors. The Hermans (2011) $\sigma\left(\mathrm{O}_{4}\right)$ data were recommended for MAX-DOAS aerosol retrievals during the CINDI campaign and were also adopted in the present study. Thalman and Volkamer (2013) found that the peak $\mathrm{O}_{4}$ cross sections for the $477 \mathrm{~nm}$ absorption band $\left(10^{-46} \mathrm{~cm}^{5} \mathrm{molec}^{-2}\right)$ were temperature dependent and were 6.60, 6.91, and 7.67 at 293, 253 , and $203 \mathrm{~K}$, respectively. Values relative to $293 \mathrm{~K}$ are $1.00,1.05$, and 1.16 , respectively. Thus, the peak $\mathrm{O}_{4}$ cross section increases by a factor of 1.05 per $40 \mathrm{~K}$ reduction of temperature from 293 to $253 \mathrm{~K}$ or $\sim 1.09 \pm 0.025$ per $44 \mathrm{~K}$ reduction from 275 to $231 \mathrm{~K}$ (Thalman and Volkamer, 2013; Spinei et al., 2015). The potential overestimation in $\triangle \mathrm{SCD}$ (obs) due to the use of smaller $\mathrm{O}_{4}$ cross-section values at a $T$ higher than the actual one can be compensated for by the same magnitude of $f_{\mathrm{O}_{4}}$, according to Eq. (1). Based on atmospheric direct sun observations, there was no pressure de-
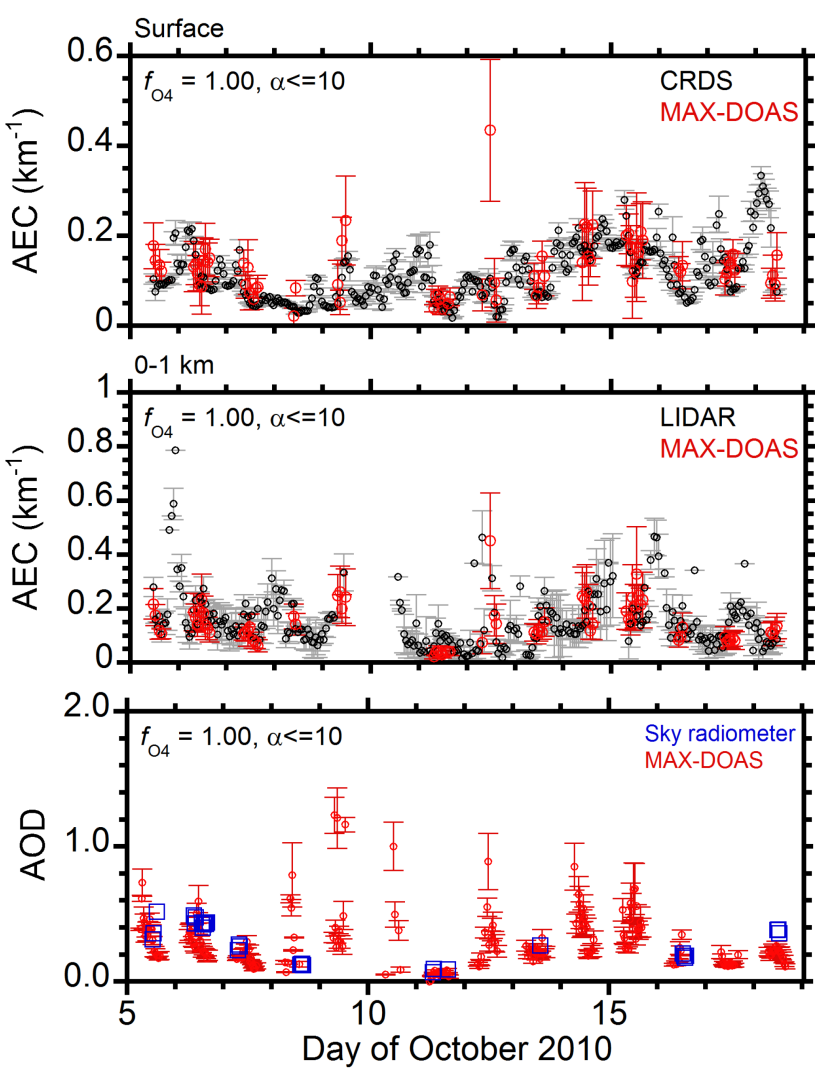

Figure 13. Same as Fig. 4, but a $f_{\mathrm{O}_{4}}=1.00$ is assumed in the MAXDOAS retrieval. $\alpha$ used in the retrieval was limited to $\leq 10^{\circ}$.

pendence of the $\mathrm{O}_{4}$ cross section within their measurement error of $3 \%$ (Spinei et al., 2015).

In contrast, we estimated the $\triangle \mathrm{SCD}$ (SCD)-based effective temperature $\left(T_{\text {eff }}\right)$ for observations in the present study (Table 1). For observations of this study, the mean surface temperature was $292 \mathrm{~K}$ with a standard deviation of $7 \mathrm{~K}$. When the surface temperature varies by $7 \mathrm{~K}$, the estimated $T_{\text {eff }}$ also varies by $7 \mathrm{~K}$ under conditions given in the caption 

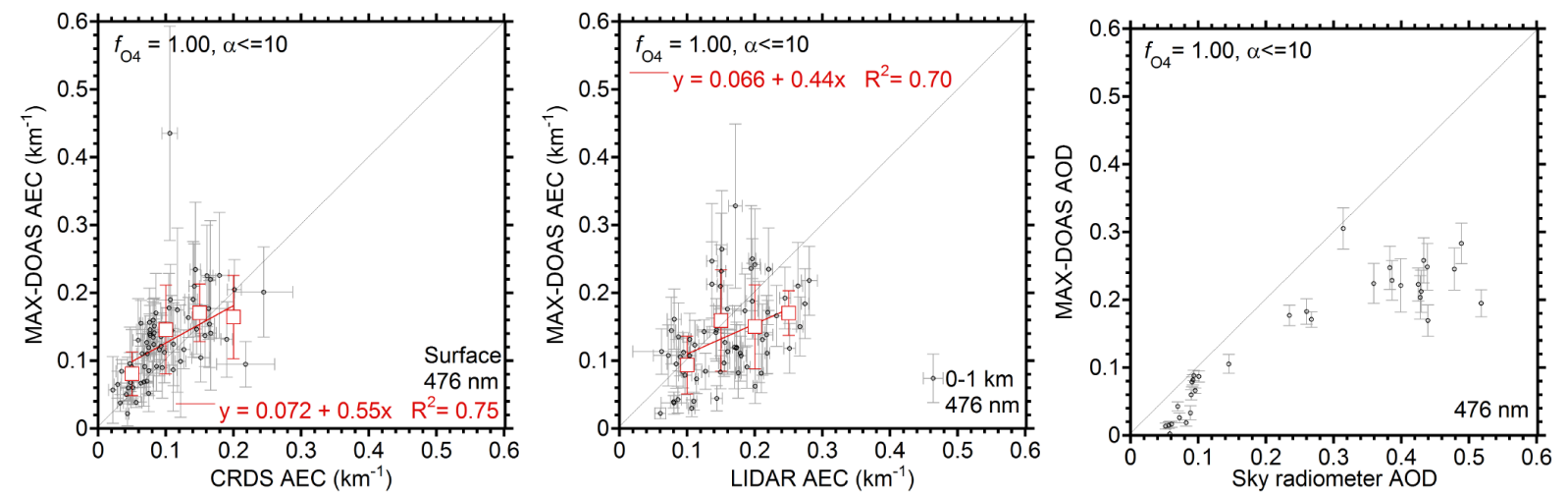

Figure 14. Same as Fig. 5, but a $f_{\mathrm{O}_{4}}=1.00$ is assumed in the MAX-DOAS retrieval. $\alpha$ used in the retrieval was limited to $\leq 10^{\circ}$.

of Table 1. However, $T_{\text {eff }}$ differences at different $\alpha$ angles

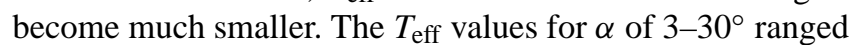
from 283 (277) to 271 (268) K, yielding a reduction of $T_{\text {eff }}$ by $12 \mathrm{~K}$, when $\alpha$ increased from $3^{\circ}$ to $30^{\circ}$. Using Eq. (6), the rate is translated to an increase of $f_{\mathrm{O}_{4}}$ by a factor of 1.45 per $12 \mathrm{~K}$ reduction in temperature. Thus, the tendency for a larger $f_{\mathrm{O}_{4}}$ to be needed at a colder $T_{\text {eff }}$ is consistent with that deduced from experiments by Thalman and Volkamer (2013) and Spinei et al. (2015), although the magnitude is different. A similar discussion has been made in the study by Spinei et al. (2015).

To investigate uncertainty in the retrieved $\Delta \mathrm{O}_{4} \mathrm{SCD}$ (obs), additional DOAS fitting was performed. Adopting Thalman and Volkamer (2013) $\mathrm{O}_{4}$ absorption cross-section data for $295 \mathrm{~K}$ increased $\Delta \mathrm{O}_{4} \mathrm{SCD}$ (obs) by $2 \%$ on average. Adopting the data for $203 \mathrm{~K}$ decreased $\Delta \mathrm{O}_{4} \mathrm{SCD}$ (obs) by $14 \%$ on average, which is comparable to the $16 \%$ change in the peak cross sections between 295 and $203 \mathrm{~K}$. In this case, however, residuals significantly increased. The combined use of the two-temperature cross-section data of Thalman and Volkamer (2013) at 295 and $203 \mathrm{~K}$ resulted in a $2 \%$ increase on average. The impact of changing the degree of polynomial and the degree of offset polynomial by \pm 1 was within $\pm 3 \%$. All of these tests were insufficient to quantitatively explain Eq. (6). However, we note here that the results from these tests do not support the accuracy of $\Delta \mathrm{O}_{4} \mathrm{SCD}$ (obs). Systematic biases might occur particularly at high $\alpha$ due to a relatively thin optical depth of $\mathrm{O}_{4}$.

The other potential cause of uncertainty is that the $\mathrm{O}_{4}$ $\triangle \mathrm{SCD}$ (mdl) may be less accurate at higher $\alpha$. However, calculations of the box AMF by various radiative transfer models were validated by Wagner et al. (2009), and larger differences among them were seen at very low $\alpha$. Therefore, this is not likely a cause. In addition, there is the fact that direct sunlight observations do not need a correction factor (Spinei et al., 2015), suggesting that this issue is only for scattered light observations. These discussions would help us identify a physical explanation of the need for a correction factor in the future.
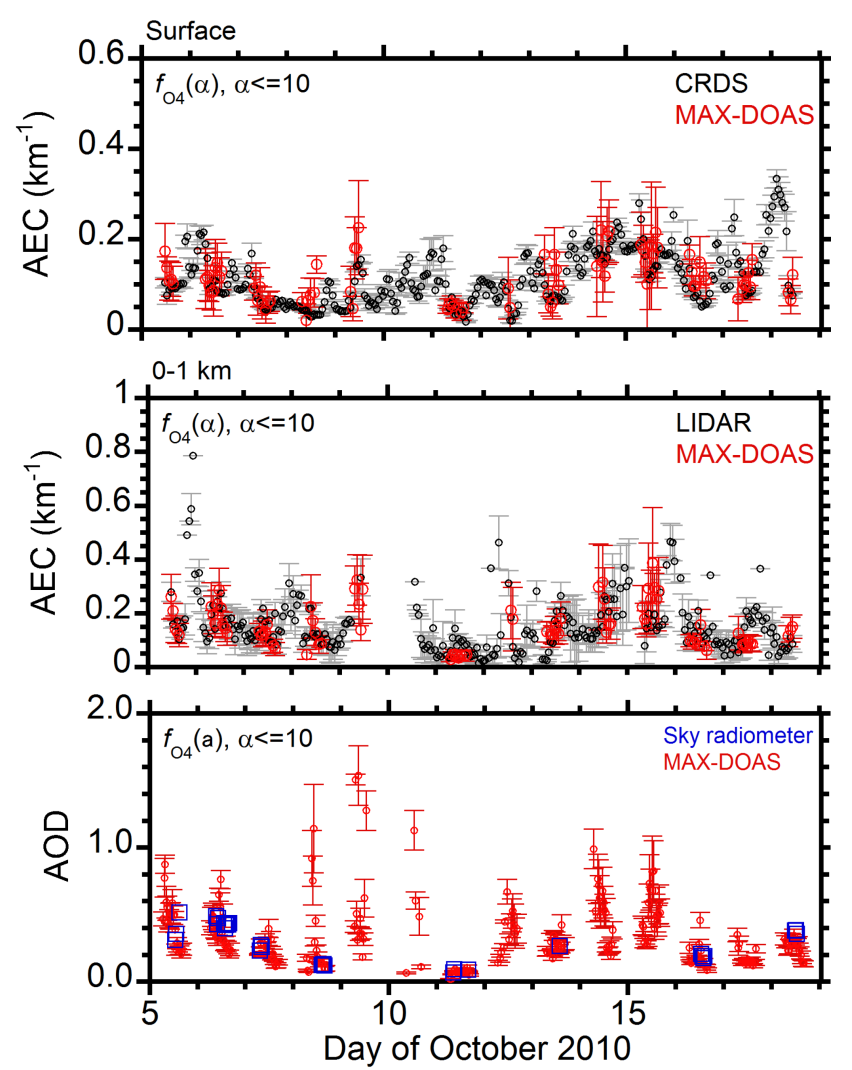

Figure 15. Same as Fig. 4, but $f_{\mathrm{O}_{4}}$ is assumed to be a function of $\alpha$ in the MAX-DOAS retrieval. $\alpha$ used in the retrieval has been limited to $\leq 10^{\circ}$.

Although the definitive physical explanations behind Eq. (6) are unclear, it is clear that problems tend to occur at relatively large $\alpha$. Considering this, as a practical solution we propose limiting the set of $\alpha$ to $\leq 10^{\circ}$ to minimize the above-mentioned potential impacts and to keep a sufficient number of $\alpha$ for each profile retrieval. Under these conditions, we tested two retrievals without (i.e., $f_{\mathrm{O}_{4}}=1.00$ ) or 

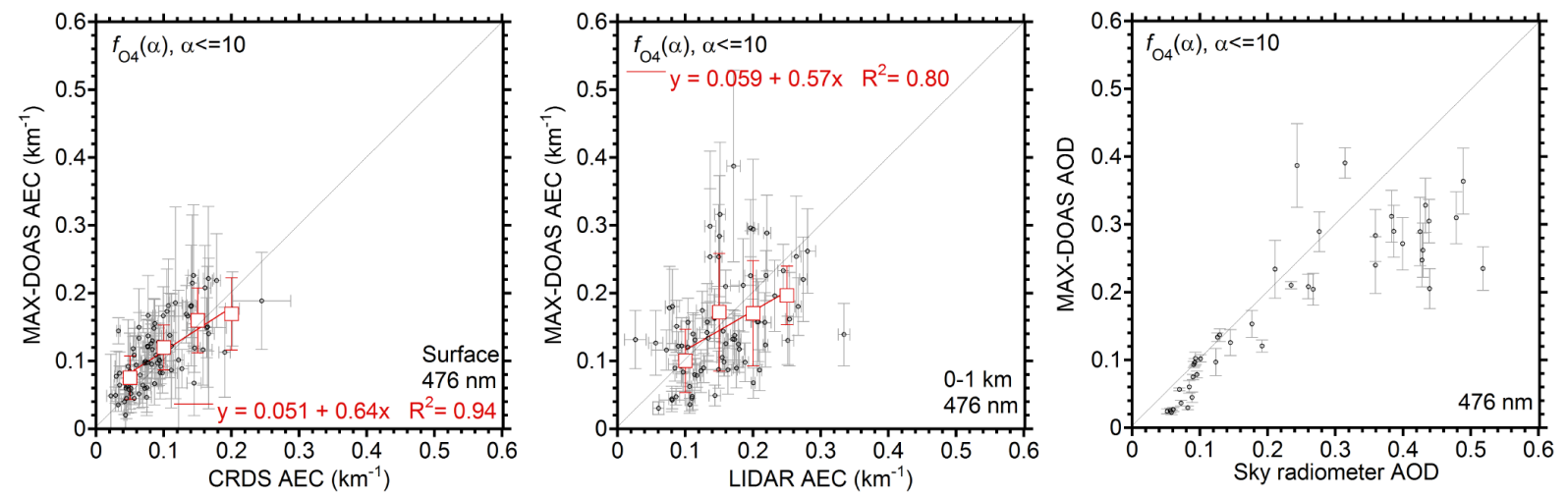

Figure 16. Same as Fig. 5, but $f_{\mathrm{O}_{4}}$ is assumed to be a function of $\alpha$ in the MAX-DOAS retrieval. $\alpha$ used in the retrieval has been limited to $\leq 10^{\circ}$.

with the correction factor $\left(f_{\mathrm{O}_{4}}=f_{\mathrm{O}_{4}}(\alpha)\right)$. The respective results are shown in Figs. 13-14 and Figs. 15-16.

Although a set of $\alpha$ is limited to $\leq 10^{\circ}$, we obtain overall reasonable agreements similar to those seen for retrievals using all $\alpha$. As the most significant difference between results from retrievals with and without the correction factor, we can see that almost all of the MAX-DOAS AOD values underestimated the sky radiometer AOD when the retrievals were performed without any correction factor (Fig. 14). In addition, for comparisons with CRDS and lidar AECs, correlations for retrievals adopting $f_{\mathrm{O}_{4}}(\alpha)$ were likely more reasonable (their respective $R^{2}$ values of 0.84 and 0.80 , and mean differences of $+0.02 \pm 0.04$ and $\left.-0.01 \pm 0.08 \mathrm{~km}^{-1}\right)$ than those without a correction factor $\left(R^{2}\right.$ of 0.75 and 0.70 , and mean differences of $+0.03 \pm 0.05$ and $-0.03 \pm 0.08 \mathrm{~km}^{-1}$ ). Therefore, we propose limiting the set of $\alpha$ to $\leq 10^{\circ}$ and adopting $f_{\mathrm{O}_{4}}(\alpha)$ for practical profile retrievals. These are encouraged to be tested by other MAX-DOAS aerosol profile retrieval algorithms.

Limiting the set of $\alpha$ to $\leq 10^{\circ}$ lowers degrees of freedom for signal (DOFS) but increases the number of available data (Table 2). The former means that observations at $\alpha$ larger than $10^{\circ}$ can contribute to an increase in DOFS. Such observations at high $\alpha$ should be added when reasons for the large $\triangle$ SCD fitting residuals found in Figs. 8 and 9 are quantitatively understood. The increased number of data again supports the tendency that fitting for $\alpha \leq 10^{\circ}$ is less subject to the correction factor than that for $\alpha=20^{\circ}$ and $30^{\circ}$. The increase in the number of data is partly due to the fact that more data under cloudy conditions became available. Excluding $\alpha$ of 20 and $30^{\circ}$ leads to the loss of sensitivity to extinction at high altitudes, where clouds are usually more dominant than aerosols. As a result, although the DOFS decreases, the capability for observing the boundary layer by MAX-DOAS is expected to be enhanced.
Table 2. DOFS and the number of available data $(N)$ for each case of correction factor.

\begin{tabular}{lrr}
\hline Correction factor and $\alpha$ range & DOFS & $N$ \\
\hline$f_{\mathrm{O}_{4}}=1.25$ and all $\alpha$ & $2.5 \pm 0.4$ & 157 \\
$f_{\mathrm{O}_{4}}=1.00$ and all $\alpha$ & $2.2 \pm 0.4$ & 107 \\
$f_{\mathrm{O}_{4}}=f_{\mathrm{O}_{4}}(\alpha)$ and all $\alpha$ & $2.4 \pm 0.4$ & 159 \\
$f_{\mathrm{O}_{4}}=1.00$ and $\alpha \leq 10^{\circ}$ & $2.0 \pm 0.3$ & 207 \\
$f_{\mathrm{O}_{4}}=f_{\mathrm{O}_{4}}(\alpha)$ and $\alpha \leq 10^{\circ}$ & $2.1 \pm 0.3$ & 229 \\
\hline
\end{tabular}

\section{Conclusions}

Coincident aerosol observations of MAX-DOAS with those of CRDS, lidar, and sky radiometer at Tsukuba, Japan, on 5-18 October 2010 were used to evaluate the MAX-DOAS aerosol retrieval from the viewpoint of the need for a correction factor for $\mathrm{O}_{4}$ absorption $\left(f_{\mathrm{O}_{4}}\right)$. After applying a $f_{\mathrm{O}_{4}}$ of 1.25 to all of the elevation angles, the retrieved near-surface AEC values were found to be significantly larger than those from the surface observations by CRDS. These results are consistent with those of Zieger et al. (2011), who analyzed data from the CINDI campaign with similar correction factors. Without any correction factor, agreement was improved. However, significant characterized residuals were left, particularly at relatively high elevation angles of 20 and $30^{\circ}$. From detailed analysis of residuals, we empirically deduced an elevation-angle-dependent correction factor (Eq. 6) that describes a larger correction factor at a higher elevation angle. This worked well to improve agreements for all comparisons with CRDS, lidar, and sky radiometer. Equation (6) accounts for the $T$ dependence of $\mathrm{O}_{4}$ absorption cross sections measured by Thalman and Volkamer (2013) qualitatively but is insufficient quantitatively. Another potential reason for the need of a correction factor is that $\mathrm{O}_{4} \Delta \mathrm{SCDs}$ derived from DOAS fit might be less accurate at higher elevation angles. Although more investigation is encouraged to quantitatively identify the cause, for minimizing such po- 
tential effects we propose to limit the set of elevation angles to $\leq 10^{\circ}$ and to adopt an elevation-angle-dependent correction factor for practical profile retrievals with scattered light observations by the ground-based MAX-DOAS.

Acknowledgements. We thank PREDE Co., Ltd. for their technical assistance in developing the MAX-DOAS instruments. The MAXDOAS observations at Tsukuba were supported by M. Nakazato. This work was performed by the joint research program of the Solar-Terrestrial Environment Laboratory, Nagoya University. This study was supported by funds from KAKENHI (numbers 25220101 and 09894399), JST/CREST/EMS/TEEDDA, and JAXA/ GCOM-C.

Edited by: A. Sayer

\section{References}

Anderson, T. L. and Ogren, J. A.: Determining aerosol radiative properties using the TSI 3563 integrating nephelometer, Aerosol Sci. Tech., 29, 55-69, 1998.

Campanelli, M., Estellés, V., Tomasi, C., Nakajima, T., Malvestuto, V., and Martinez-Lozano, J. A.: Application of the SKYRAD improved Langley plot method for the in situ calibration of CIMEL sun-sky photometers, Appl. Optics, 46, 2688-2702, 2007.

Campanelli, M., Lupi, A., Nakajima, T., Malvestuto, V., Tomasi, C., and Estelles, V.: Summertime columnar content of atmospheric water vapor from ground-based Sun-sky radiometer measurements through a new in situ procedure, J. Geophys. Res., 115, D19304, doi:10.1029/2009JD013211, 2010.

Che, H., Shi, G., Uchiyama, A., Yamazaki, A., Chen, H., Goloub, P., and Zhang, X.: Intercomparison between aerosol optical properties by a PREDE skyradiometer and CIMEL sunphotometer over Beijing, China, Atmos. Chem. Phys., 8, 3199-3214, doi:10.5194/acp-8-3199-2008, 2008.

Clémer, K., Van Roozendael, M., Fayt, C., Hendrick, F., Hermans, C., Pinardi, G., Spurr, R., Wang, P., and De Mazière, M.: Multiple wavelength retrieval of tropospheric aerosol optical properties from MAXDOAS measurements in Beijing, Atmos. Meas. Tech., 3, 863-878, doi:10.5194/amt-3-863-2010, 2010.

Frieß, U., Monks, P. S., Remedios, J.J., Rozanov, A., Sinreich, R., Wagner, T., and Platt, U.: MAX-DOAS $\mathrm{O}_{4}$ measurements: A new technique to derive information on atmospheric aerosols: 2. Modeling studies, J. Geophys. Res., 111, D14203, doi:10.1029/2005JD006618, 2006.

Hermans, C.: $\mathrm{O}_{4}$ absorption cross-sections at $296 \mathrm{~K}$ (335.59$666.63 \mathrm{~nm}$ ), available at: http://spectrolab.aeronomie.be (last access: 1 July 2011), 2011.

Higurashi, A. and Nakajima, T.: Detection of aerosol types over the East China Sea near Japan from four-channel satellite data, Geophys. Res. Lett., 29, 1836, doi:10.1029/2002GL015357, 2002.

Hönninger, G. and Platt, U.: Observations of BrO and its vertical distribution during surface ozone depletion at Alert, Atmos. Environ., 36, 2481-2489, 2002.
Hönninger, G., von Friedeburg, C., and Platt, U.: Multi axis differential optical absorption spectroscopy (MAX-DOAS), Atmos. Chem. Phys., 4, 231-254, doi:10.5194/acp-4-231-2004, 2004.

Intergovernmental Panel on Climate Change (IPCC): Summary for Policymakers, in: Climate Change 2013: The Physical Science Basis. Contribution of Working Group I to the Fifth Assessment Report of the Intergovernmental Panel on Climate Change, edited by: Stocker, T. F., Qin, D., Plattner, G.-K., Tignor, M., Allen, S. K., Boschung, J., Nauels, A., Xia, Y., Bex, V., and Midgley, P. M., Cambridge University Press, Cambridge, United Kingdom and New York, NY, USA, 2013.

Irie, H., Kanaya, Y., Akimoto, H., Iwabuchi, H., Shimizu, A., and Aoki, K.: First retrieval of tropospheric aerosol profiles using MAX-DOAS and comparison with lidar and sky radiometer measurements, Atmos. Chem. Phys., 8, 341-350, doi:10.5194/acp-8341-2008, 2008a.

Irie, H., Kanaya, Y., Akimoto, H., Tanimoto, H., Wang, Z., Gleason, J. F., and Bucsela, E. J.: Validation of OMI tropospheric $\mathrm{NO}_{2}$ column data using MAX-DOAS measurements deep inside the North China Plain in June 2006: Mount Tai Experiment 2006, Atmos. Chem. Phys., 8, 6577-6586, doi:10.5194/acp-8-6577-2008, 2008 b.

Irie, H., Kanaya, Y., Akimoto, H., Iwabuchi, H., Shimizu, A., and Aoki, K.: Dual-wavelength aerosol vertical profile measurements by MAX-DOAS at Tsukuba, Japan, Atmos. Chem. Phys., 9, 2741-2749, doi:10.5194/acp-9-2741-2009, 2009.

Irie, H., Takashima, H., Kanaya, Y., Boersma, K. F., Gast, L., Wittrock, F., Brunner, D., Zhou, Y., and Van Roozendael, M.: Eightcomponent retrievals from ground-based MAX-DOAS observations, Atmos. Meas. Tech., 4, 1027-1044, doi:10.5194/amt-41027-2011, 2011.

Iwabuchi, H.: Efficient Monte Carlo methods for radiative transfer modeling, J. Atmos. Sci., 63, 2324-2339, 2006.

Kanaya, Y., Irie, H., Takashima, H., Iwabuchi, H., Akimoto, H., Sudo, K., Gu, M., Chong, J., Kim, Y. J., Lee, H., Li, A., Si, F., Xu, J., Xie, P.-H., Liu, W.-Q., Dzhola, A., Postylyakov, O., Ivanov, V., Grechko, E., Terpugova, S., and Panchenko, M.: Long-term MAX-DOAS network observations of $\mathrm{NO}_{2}$ in Russia and Asia (MADRAS) during the period 2007-2012: instrumentation, elucidation of climatology, and comparisons with OMI satellite observations and global model simulations, Atmos. Chem. Phys., 14, 7909-7927, doi:10.5194/acp-14-7909-2014, 2014.

Khatri, P., Takamura, T., Shimizu, A., and Sugimoto, N.: Spectral dependency of aerosol light-absorption over the East China Sea region, SOLA, 6, 1-4, doi:10.2151/sola.2010-001, 2010.

Kim, D. H., Sohn, B. J., Nakajima, T., and Takamura, T.: Aerosol radiative forcing over east Asia determined from ground-based solar radiation measurements, J. Geophys. Res., 110, D10S22, doi:10.1029/2004JD004678, 2005.

Kurucz, R. L., Furenlid, I., Brault, J., and Testerman, L.: Solar flux atlas from 296 to 1300 nm, Natl. Sol. Obs., Sunspot, New Mexico, 240 pp., 1984.

Nakajima, T., Tonna, G., Rao, R., Boi, P., Kaufman, Y., and Holben, B.: Use of sky brightness measurements from ground for remote sensing of particulate polydispersions, Appl. Opt., 35, 2672-2686, 1996.

Nakajima, T., Yoon, S. C., Ramanathan, V., Shi, G. Y., Takemura, T., Higurashi, A., Takamura, T., Aoki, K., Sohn, B. J., Kim, S. W., Tsuruta, H., Sugimoto, N., Shimizu, A., Tanimoto, H., 
Sawa, Y., Lin, N. H., Lee, C. T., Goto, D., and Schutgens, N.: Overview of the Atmospheric Brown Cloud East Asian Regional Experiment 2005 and a study of the aerosol direct radiative forcing in east Asia, J. Geophys. Res., 112, D24S91, doi:10.1029/2007JD009009, 2007.

Nakayama, T., Hagino, R., Matsumi, Y., Sakamoto, Y., Kawasaki, M., Yamazaki, A., Uchiyama, A., Kudo, R., Moteki, N., Kondo, Y., and Tonokura, K.: Measurements of aerosol optical properties in central Tokyo during summertime using cavity ring-down spectroscopy: Comparison with conventional techniques, Atmos. Environ., 44, 3034-3042, 2010a.

Nakayama, T., Matsumi, Y., Sato, K., Imamura, T., Yamasaki, and Uchiyama, A.: Laboratory studies on optical properties of secondary organic aerosols generated during the photooxidation of toluene and the ozonolysis of $\alpha$-pinene, J. Geophys. Res., 115, D24204, doi:10.1029/2010JD014387, 2010b.

Ogren, J. A.: Comment on "calibration and intercomparison of filter-based measurements of visible light absorption by aerosols", Aerosol Sci. Tech., 44, 589-591, 2010.

Pandithurai, G., Takamura, T., Yamaguchi, J., Miyagi, K., Takano, T., Ishizaka, Y., Dipu, S., and Shimizu, A.: Aerosol effect on cloud droplet size as monitored from surface-based remote sensing over East China Sea region, Geophys. Res. Lett., 36, L13805, doi:10.1029/2009GL038451, 2009.

Piters, A. J. M., Boersma, K. F., Kroon, M., Hains, J. C., Van Roozendael, M., Wittrock, F., Abuhassan, N., Adams, C., Akrami, M., Allaart, M. A. F., Apituley, A., Beirle, S., Bergwerff, J. B., Berkhout, A. J. C., Brunner, D., Cede, A., Chong, J., Clémer, K., Fayt, C., Frieß, U., Gast, L. F. L., Gil-Ojeda, M., Goutail, F., Graves, R., Griesfeller, A., Großmann, K., Hemerijckx, G., Hendrick, F., Henzing, B., Herman, J., Hermans, C., Hoexum, M., van der Hoff, G. R., Irie, H., Johnston, P. V., Kanaya, Y., Kim, Y. J., Klein Baltink, H., Kreher, K., de Leeuw, G., Leigh, R., Merlaud, A., Moerman, M. M., Monks, P. S., Mount, G. H., Navarro-Comas, M., Oetjen, H., Pazmino, A., Perez-Camacho, M., Peters, E., du Piesanie, A., Pinardi, G., Puentedura, O., Richter, A., Roscoe, H. K., Schönhardt, A., Schwarzenbach, B., Shaiganfar, R., Sluis, W., Spinei, E., Stolk, A. P., Strong, K., Swart, D. P. J., Takashima, H., Vlemmix, T., Vrekoussis, M., Wagner, T., Whyte, C., Wilson, K. M., Yela, M., Yilmaz, S., Zieger, P., and Zhou, Y.: The Cabauw Intercomparison campaign for Nitrogen Dioxide measuring Instruments (CINDI): design, execution, and early results, Atmos. Meas. Tech., 5, 457-485, doi:10.5194/amt-5-457-2012, 2012.

Platt, U.: Differential optical absorption spectroscopy (DOAS), Air Monitoring by Spectroscopic Techniques, 127, 27-84, edited by: Sigrist, M. W., John Wiley \& Sons, Inc., New York, 1994.

Platt, U. and Stutz, J.: Differential Optical Absorption spectroscopy, Principles and Applications, Springer, XV, 597 pp., 272 illus., 29 in color, Physics of Earth and Space Environments, ISBN 978-3540-21193-8, 2008.

Rodgers, C. D.: Inverse methods for atmospheric sounding: Theory and practice, Ser. Atmos. Oceanic Planet. Phys., 2, edited by: Taylor, F. W., World Sci., Hackensack, NJ, 2000.

Roscoe, H. K., Van Roozendael, M., Fayt, C., du Piesanie, A., Abuhassan, N., Adams, C., Akrami, M., Cede, A., Chong, J., Clémer, K., Frieß, U., Gil Ojeda, M., Goutail, F., Graves, R., Griesfeller, A., Grossmann, K., Hemerijckx, G., Hendrick, F., Herman, J., Hermans, C., Irie, H., Johnston, P. V., Kanaya, Y.,
Kreher, K., Leigh, R., Merlaud, A., Mount, G. H., Navarro, M., Oetjen, H., Pazmino, A., Perez-Camacho, M., Peters, E., Pinardi, G., Puentedura, O., Richter, A., Schönhardt, A., Shaiganfar, R., Spinei, E., Strong, K., Takashima, H., Vlemmix, T., Vrekoussis, M., Wagner, T., Wittrock, F., Yela, M., Yilmaz, S., Boersma, F., Hains, J., Kroon, M., Piters, A., and Kim, Y. J.: Intercomparison of slant column measurements of $\mathrm{NO}_{2}$ and $\mathrm{O}_{4}$ by MAX-DOAS and zenith-sky UV and visible spectrometers, Atmos. Meas. Tech., 3, 1629-1646, doi:10.5194/amt-3-1629-2010, 2010.

Shimizu, A., Sugimoto, N., Matsui, I., Arao, K., Uno, I., Murayama, T., Kagawa, N., Aoki, K., Uchiyama, A., and Yamazaki, A.: Continuous observations of Asian dust and other aerosols by polarization lidars in China and Japan during ACE-Asia, J. Geophys. Res., 109, D19S17, doi:10.1029/2002JD003253, 2004.

Sneep, M. and Ubachs, W.: Cavity Ring-Down Measurements of the $\mathrm{O}_{2}-\mathrm{O}_{2}$ collision induced absorption resonance at $477 \mathrm{~nm}$ at sub-atmospheric pressures, J. Quant. Spectrosc. Radiat. Transfer, 78, 171-178, 2003.

Sohn, B. J., Nakajima, T., Chun, H. W., and Aoki, K.: More absorbing dust aerosol inferred from sky radiometer measurements at Anmyeon, Korea, J. Meteorol. Soc. Jpn., 85, 815-823, 2007.

Spinei, E., Cede, A., Herman, J., Mount, G. H., Eloranta, E., Morley, B., Baidar, S., Dix, B., Ortega, I., Koenig, T., and Volkamer, R.: Ground-based direct-sun DOAS and airborne MAX-DOAS measurements of the collision-induced oxygen complex, $\mathrm{O}_{2} \mathrm{O}_{2}$, absorption with significant pressure and temperature differences, Atmos. Meas. Tech., 8, 793-809, doi:10.5194/amt-8-793-2015, 2015.

Takenaka, H., Nakajima, T. Y., Higurashi, A., Higuchi, A., Takamura, T., Pinker, R. T., and Nakajima, T.: Estimation of solar radiation using a neural network based on radiative transfer, $\mathrm{J}$. Geophys. Res., 116, D08215, doi:10.1029/2009JD013337, 2011.

Thalman, R. and Volkamer, R.: Temperature dependent absorption cross-sections of $\mathrm{O}_{2}-\mathrm{O}_{2}$ collision pairs between 340 and $630 \mathrm{~nm}$ and at atmospherically relevant pressure, Phys. Chem. Chem. Phys., 15, 15371, doi:10.1039/c3cp50968k, 2013.

Uchiyama, A., Yamazaki, A., Kudo, R., Kobayashi, E., Togawa, H., and Uesawa, D., Continuous ground-based observation of aerosol optical properties at Tsukuba, Japan: Trend and climatology, J. Meteor. Soc. Japan, 92A, 93-108, 2014.

Wagner, T., Burrows, J. P., Deutschmann, T., Dix, B., von Friedeburg, C., Frieß, U., Hendrick, F., Heue, K.-P., Irie, H., Iwabuchi, H., Kanaya, Y., Keller, J., McLinden, C. A., Oetjen, H., Palazzi, E., Petritoli, A., Platt, U., Postylyakov, O., Pukite, J., Richter, A., van Roozendael, M., Rozanov, A., Rozanov, V., Sinreich, R., Sanghavi, S., and Wittrock, F.: Comparison of box-airmass-factors and radiances for Multiple-Axis Differential Optical Absorption Spectroscopy (MAX-DOAS) geometries calculated from different UV/visible radiative transfer models, Atmos. Chem. Phys., 7, 1809-1833, doi:10.5194/acp-7-1809-2007, 2007.

Wagner, T., Deutschmann, T., and Platt, U.: Determination of aerosol properties from MAX-DOAS observations of the Ring effect, Atmos. Meas. Tech., 2, 495-512, doi:10.5194/amt-2-4952009, 2009.

Wittrock, F., Oetjen, H., Richter, A., Fietkau, S., Medeke, T., Rozanov, A., and Burrows, J. P.: MAX-DOAS measurements of atmospheric trace gases in Ny-Ålesund - Radiative transfer 
studies and their application, Atmos. Chem. Phys., 4, 955-966, doi:10.5194/acp-4-955-2004, 2004.

Zieger, P., Weingartner, E., Henzing, J., Moerman, M., de Leeuw, G., Mikkilä, J., Ehn, M., Petäjä, T., Clémer, K., van Roozendael, M., Yilmaz, S., Frieß, U., Irie, H., Wagner, T., Shaiganfar, R., Beirle, S., Apituley, A., Wilson, K., and Baltensperger, U.: Comparison of ambient aerosol extinction coefficients obtained from in-situ, MAX-DOAS and LIDAR measurements at Cabauw, Atmos. Chem. Phys., 11, 2603-2624, doi:10.5194/acp11-2603-2011, 2011. 